\title{
A Christian Approach to Education for Sustainable Development
}

\author{
Mary-Noelle Ethel Ezeh \\ Anambra State University, Uli, Nigeria
}

\begin{abstract}
In declaring 2005-2014 Decade of Education for Sustainable Development (DESD), the United Nations challenge all countries to integrate the principles, values, and practices of sustainable development into their education and learning policies and programmes at all levels. The concept of sustainable development, first used in 1987 Brundtland World Commission Report, has itself since evolved from its narrow two foci use on environment and development process, to include broader dimensions that integrate economic, ecological, social, and spiritual well-being which promote the quality of life. But a proper integration of these four pillars of sustainable development into education and learning process requires an innovative and interdisciplinary approach. Sustainable development is a scientific concept which builds on observable facts as well as an ethical imperative which demands critical reflection on responsible human action. The objective of this study is therefore to critically examine how the content and practices of the Christian faith teach and enhance responsible action for sustainable development. Firstly, the paper analyses some key Biblical values that foster sustainable development. Secondly, it demonstrates how the basic principles of Catholic social teaching correspond with and promote the principles of sustainable development. Thirdly, it highlights some Christian activities that promote sustainable development. Finally, the paper concludes by recommending a greater integration of the Christian value-based education into the education and learning system in Africa.
\end{abstract}

Keywords: education, economic, ecological, social, spiritual well-being

2005-2014 has been declared the Decade of Education for Sustainable Development (DESD). Education for Sustainable Development (ESD) is a vision of education that seeks to balance human and economic well-being with cultural traditions and respect for the earth's natural resources (United Nations Educational, Scientific, and Cultural Organization [UNESCO], 2002). The concept of sustainable development was first used in 1987 in the context of the report titled: Our Common Future by the World Commission on Environment and Development, headed by Gro Harlem Brundtland. In the Brundtland Report (1987), the focus of the concept was on environment and development policies and not on education. It was in the Rio Earth Summit of 1992 that the crucial importance of education was highlighted. Education was then acknowledged to be "critical for promoting sustainable development and improving the capacity of the people to address environmental and development issues"1. UNESCO was charged with the responsibility of providing support and developing pedagogical material for sustainable development education. Goal 7 of the Millennium Development Goals (MDGs) (2000) calls for concerted efforts to "integrate the principles of sustainable development into countries' policies and reverse the

Corresponding author: Mary-Noelle Ethel Ezeh, Ph.D., DD, PGDE, lecturer, associate professor, Department of Religion and Society, Anambra State University, Nigeria; research fields: ethics, integration of science, religion and education. E-mail: ezehngozika81@yahoo.com.

${ }^{1}$ Retrieved from http://www.unesco.org/education/desd. 
present trend of loss of natural resources"2. In 2002, to ensure a more pragmatic and comprehensive implementation of sustainable development, the United Nations declared 2005-2014 as the DESD. It is a declaration that challenges all nations to integrate the principles, values, and practices of sustainable development into their education policies and learning programmes at all levels. Sustainable development is both a scientific concept and an ethical imperative. As a scientific concept, it builds on observable facts and, as an ethical precept; it demands critical reflection on responsible human action. There is therefore a great need for an innovative and interdisciplinary approach for proper integration into the education and learning process, the four pillars of sustainable development namely: economics, ecology, social, and spiritual well-being. In response to this felt need, the study is set to analyse how the Christian faith teaches and communicates the spiritual dimension of sustainable development. In the first phase, the paper explores the Biblical perspective of values that foster sustainable development. In the second phase, the study examines the Christian contemporary approach to sustainable development and demonstrates how its basic ideas correspond with and promote the principles of sustainable development. The third phase is concerned with Christian pedagogy and activities that enhance sustainable development. In conclusion, the paper recommends a greater inclusion of Christian value-based education into education and learning systems for a proper integration of the spiritual dimension of sustainable development.

\section{Biblical Values That Foster Sustainable Development}

\section{Creation Is God's Gift to Humanity}

The Biblical narrative uses the term "creation" rather than "nature" to describe the physical world or the natural environment. From the Biblical point of view, creation is the work of God who sustains it and directs it toward a purpose (Gen $1 \& 2$ ) (Christian Scripture, the book of Genesis Chapters $1 \& 2$ ). The created world has therefore a fundamental value in itself irrespective of its utility to humanity. Indeed, the various Biblical passages affirm that creation is not simply a utilitarian instrument, to be exploited and manipulated by humans; rather creation finds its fulfilment in God the Creator (Ps 19, 89, 104; Job 39-41) (Christian Scripture, Psalms 19, 89, 109; book of Job Chapters 39-41). Since the Scientific Revolution and the Enlightenment in Western culture, the term "nature" has sometimes been perceived by some scholars and the general public from the perspective of a strong anthropocentric bias that interprets nature as raw material of an instrumental value which receives its value only through human technological exploitation (Haught, 1995; Barbour, 1990; Stoutzenberger, 2012). The pragmatic benefits of such materialistic mentality are as remarkable as the destructive power which is threatening the survival of life on earth (Birch, 1991). But from the Biblical perspective, God proclaimed the created order very good (Gen 1: 4, 13, 18, 25) (Genesis Chapter 1 verses 4, 13, 18, 25) even before the appearance of human beings on earth (Ezeh, 2012). The creation of human beings is presented as unique because man and woman are the only beings said to be created in the "image and likeness of God", the imago Dei (Gen 1: 27) (Genesis Chapter 1 verse 27). This uniqueness of imago Dei singles human beings out for responsibility over the rest of God's creation. Creation is therefore God's gift of trust to humanity. ESD challenges us to appreciate the Biblical notion of creation as a gift of trust and responsibility. In practice, this would engender an attitude of respect and of relation that is not exclusively utilitarian toward the created world.

\section{Respect and Responsibility}

From the Biblical perspective, human beings do not have absolute and unlimited dominion over the earth.

${ }^{2}$ Retrieved from http://www.un.org/millennium/summit.htm. 
They are rather responsible caretakers to whom God, the creator, and owner, entrusted the earth to till it and care for it (Gen 2: 15) (Genesis Chapter 2 verse 15). Browning (2012) has rightly noted that the apparent contradiction between the Biblical commission "to subdue and have dominion" over the earth in Gen 1: 28 (Genesis Chapter 1 verse 28); and the mission "to till and care for" for the earth in Gen 2:15 (Genesis Chapter 2 verse 15) reflects rather the reality of human experience of tension involved in being a part of creation and yet being apart from it. It is a tension that oscillates between absolute dominion, as advocated by those who cite Gen 1: 28 (Genesis Chapter 1 verse 28) to rationalise unbridled economic and technological exploitation on the one hand and, on the other hand, harmony, as upheld by people who quote Gen 2:15 (Genesis Chapter 2 verse $15)$ to call for human respect for the ecosystem. Supporting this second position, Boff (2012) asserts that:

There is an affirmation that comes from Genesis Chapter 2 in which is mentioned that the mission of human beings in the Garden of Eden - that is to say, on earth is "to care and protect". "To care" is to have a loving and non-destructive relationship with creation. "To protect" is equivalent to guaranteeing the sustainability of all beings, in the sense of keeping them alive, allowing them to reproduce and evolve. (Boff, 2012, p. 23)

Christian approach of education for sustainable development therefore advocates an attitude of respect, care, and protection of the ecosystems for a flourishing of life on earth for all generations.

\section{Harmony and Kinship}

There is a fundamental Biblical belief that all created beings are interconnected. This is highlighted in the second Biblical narrative of the creation of human being in Genesis Chapter 2. The narrative exhibits a play of words in which the Hebrew name given to humanity "Adam" is derived from adamah, meaning earth. The Lord God is presented as fashioning Adam from the soil. This underscores the relatedness of human being to the earth. Human kinship with the rest of creation means that human beings and the rest of creation are mutually interconnected and interdependent. Yet even here, the most crucial factor in human emergence, the breath of life, is not derived from the earth but from the breath of Yahweh (McDonagh, 1994). Re-educating ourselves to appreciate the Biblical value of kinship with the earth will encourage an attitude of harmony with the rest of creation since the destiny of humanity is inextricably tied to the health and well-being of non-human creation (Browning, 2012).

\section{Catholic Social Teaching and the Earth Charter's Basic Principles of Sustainable Development}

Catholic social teaching was developed in the 19th and 20th centuries in the wake of modern industrial state with its new social structures, new concept of society, state, and authority, and new form of labour and ownership. It is the official teaching of the Catholic Church on social, economic, political, and environmental issues. It is grounded on the Biblical and Christian philosophical understanding of the human person and human relation in society and to the created world. It embodies basic Christian values most of which have influenced the philosophical underpinnings of the fundamental ethical principle of in the modern society. On the other hand, the Earth Charter, officially launched on June 29, 2000, is an international declaration of fundamental values and principles for building a just, sustainable, and peaceful society in the 21 st century. It is an ethical vision that works to integrate environmental protection, human rights, economic development, and peace-building issues. The basic ethical principles of the Earth Charter correspond to the Catholic social teaching. Table 1 below represents a summary of the fundamental Christian values expounded by the Catholic 
social teaching and their corresponding ethical principles as reflected in the Earth Charter.

Table 1

Core Catholic Social Teaching and the Corresponding Ethical Principles of the Earth Charter

\begin{tabular}{|l|l|}
\hline Catholic social teaching (CST) & Earth Charter (EC) \\
\hline Human dignity & $\begin{array}{l}\text { Respect and care for the community of life } \\
1 . \text { Respect earth and life in all its diversity; }\end{array}$
\end{tabular}

1. Human being is made in the image and likeness of God (Gen 2. Care for the community of life with understanding, $1: 27)$;

2. Human dignity guarantees human rights and responsibilities (Leo XIII, 1891; John Paul II, 1989; Vatican II, 1963).

compassion, and love;

3. Build democratic societies that are just, participatory, sustainable, and peaceful;

4. Secure Earth's bounty and beauty for present and future generations.

Ecological integrity

5. Protect and respect the integrity of Earth's ecological

Human stewardship and responsibility for the earth

1. Human beings are part of creation;

2. They are entrusted to care for creation and subdue it; systems, with special concern for biological diversity and the natural processes that sustain life;

3. Freedom imposes tasks and responsibilities;

6. Prevent harm as the best method of environmental protection and, when knowledge is limited, apply precautionary approach;

4. Human beings have moral responsibility over the way to deal 7. Adopt patterns of production, consumption, and reproduction with created order (John Paul II, 1990).

that safeguard Earth's regenerative capacities, human rights, and community well-being;

8. Advance the study of ecological sustainability and promote the open exchange and wide application of knowledge acquired.

Social and economic justice

9. Eradicate poverty as an ethical, social, and environmental imperative;

Social justice and charity

1. Social justice is the fundamental principle of social order and

10. Ensure that economic activities and institutions at all levels peace;

promote human development in an equitable and sustainable

2. Charity/Option for the poor is the fundamental principle of Christian ethics (Leo XIII, 1891; John XXIII, 1963; Pius XI, 1931; Vatican II, 1965).

11. Affirm gender equality and equity as prerequisites to sustainable development and ensure universal access to education, health care, and economic opportunity;

12. Uphold the right of all, without discrimination, to a natural and social environment supportive of human dignity, bodily health, and spiritual well-being, with special attention to the rights of indigenous peoples and minorities.

Solidarity and subsidiarity

Democracy, non-violence, and peace

1. The human person is a social being in need of relationship at 13. Strengthen democratic institutions at all levels, and provide different levels for existence, security, and growth;

2. Powers and responsibilities are to be delegated to the appropriate levels of authority without undue interference;

3. Solidarity and subsidiarity values are based on human freedom and responsibility (Leo XIII, 1891; Pius XI, 1931).

transparency and accountability to governance, inclusive participation in decision-making, and access to justice;

14. Integrate into formal education and lifelong learning and knowledge, values, and skills needed for a sustainable way of life;

The common good

1. One's dignity, rights, and needs are in constant interaction with those of others;

2. The manner a society is organised in economics, politics, and law invariably affects the capacity of the individuals to grow in community;

3. Everyone has the responsibility to contribute to the common good and the right to be served from it (Leo XIII, 1891; John XXIII, 1961).

Human labour

1. Labour is part of the value of human dignity;

2. It is participation in God's creative work and in fulfilment of the divine commission in Gen 1:28 and the corresponding mission in Gen 2:15 (Leo XIII, 1891; John Paul II, 1981). 


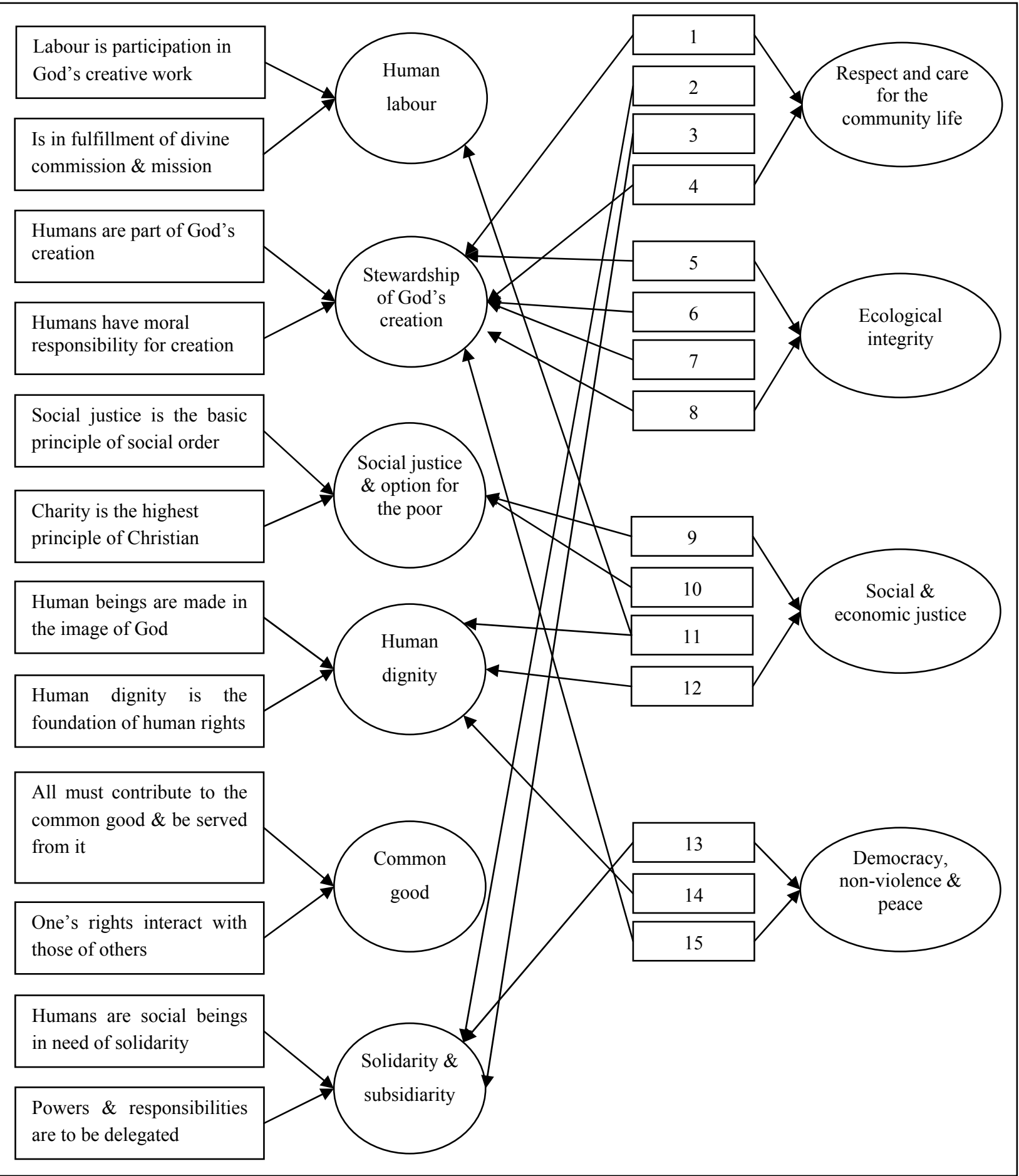

Figure 1. Catholic social teaching and the ethical principles of Earth Charter.

The Catholic social teachings and the Earth Charter constitute the fundamental values and ethical principles for education for sustainable development. Figure 1 is a representation of the correlation between them. 


\section{Christian Practices That Promote Sustainable Development}

Christian approach to ESD engages in practices and value-based education that promote sustainability. Some of these activities include:

\section{Anti-Human Trafficking}

The imperative of sustainable development is very much tied to respect for human dignity as indicated by the Catholic social teaching as well as the principles of the Earth Charter No. 11. The principle of human dignity is a fundamental Christian value. Human trafficking is a violation and direct assault to human dignity. Many Christian agencies and non-governmental organizations (NGOs) engage themselves in anti-human activities. Such Christian practices form part of ESD. The Nigeria Conference of Women Religious (NCWR), for example, has set up a committee for the support of the dignity of women in Benin City as its organ of anti-human trafficking. The committee carries out many activities for the promotion of human dignity through anti-human trafficking. In line with this, the committee:

(1) Conducts educational presentation on the promotion of human dignity for families, the youth, and the general public;

(2) Engages itself in rescue mission of victims of human trafficking;

(3) Resettles and rehabilitates rescued victims;

(4) Organises training/workshop for skill acquisition;

(5) Collaborates with government and non-governmental agencies in the fight against human trafficking.

\section{Poverty Alleviation}

Christian social action of poverty alleviation is an eloquent testimony of ESD. The acid test of the moral standard of any society is how it treats its vulnerable members. Through its long history, the Christian religion has always been known for its action in favour of the less privileged of the society. Christian religions bodies and organisations engaged themselves in activities that:

(1) Empower the poor with education and resources to secure a sustainable livelihood;

(2) Provide for the needy and the margins of the society;

(3) Create awareness, awaken politician, and sensitise public consciousness to the plight of the poor.

This Christian long active involvement in poverty alleviation is buttressed in our day by the Millennium Goals and the principles of the Earth Charter which emphasize the link between poverty alleviation and sustainable development.

\section{Religious Celebrations}

Certain Christian celebrations constitute practical ESD. This is true of the liturgical Ash Wednesday celebration that marks the beginning of Lent, the Christian penitential period. In the Catholic liturgy, the faithful are marked with ashes on the forehead with the following word: "Remember that you are dust and unto dust you shall return". This simple liturgy teaches Christian to remember and live their interconnectedness with the earth and challenges them to adopt attitude and behaviour that is imbued with humility and reverence for the earth to which we must all return. In the same way, some liturgical activities of the Orthodox Church assure education for sustainable development. According to Mansour (2012),

The Orthodox Church also regularly practices fasting, usually at the beginning of winter and the beginning of spring, seasons that are important in the life cycle of all creatures. This fasting is entirely vegan, eliminating all animal products, 
including dairy. The purpose of the tradition is to ask adherents of the faith to quit unnecessary lifestyles, and instead participate in sustainable lifestyles which both eliminate the gap between the rich and poor, and strengthen friendship between humans and nature. (Mansour, 2012, p. 33)

\section{Community Development for Sustainable Living}

Christian ESD is also practised through community development projects. For many centuries, Christian monasteries have been known to be engaged in large scale agro-business based on sustainable farming. There are also Christian organisations that practice small and large scale sustainable farming that produce healthy food and promote healthy lifestyle. Many Christian based community projects practice and encourage environmental action that educate and promote reduction of wastes, the reuse and recycle of papers, cans, bottles, plastics and all recyclable objects for sustainable living and the preservation of the ecosystem.

\section{Conclusions}

The Earth Charter and UNESCO have pointed out the vital importance of developing the spiritual dimension of sustainable development and of inculcating it into our education system. The study has demonstrated the Christian values and praxis that enhance education for sustainable development. It has also highlighted the significant synergy between Christian values and the ethical principles of sustainable development which could be integrated into the education system. Promoting education for sustainable development would however require a paradigm shift from the materialistic mentality of possessing and having more to a spiritual mindset of being more and sharing with others, including the future generations, which is then translated into change in human attitude, policies, and practices. To achieve this, the study has put forward some recommendations.

\section{Recommendations}

(1) Prioritize value-based education in the school curriculum content;

(2) Restructure education programmes to include environmental education at all levels;

(3) Integrate the study of ethics in the curriculum of all science-based disciplines;

(4) Encourage religious practices and celebrations that are ecological friendly;

(5) Subsidize faith-based community projects that promote education for sustainable development;

(6) Encourage and emphasize interdisciplinary research for sustainable development among religion, philosophy, and science-based disciplines;

(7) Use learning and teaching methods that promote the principles of sustainable development.

\section{References}

Barbour, I. G. (1990). Religion in the age of science. London: SCM Press.

Birch, C. (1991). Christian obligation for the liberation of life. In C. Birch, W. Eakin, and J. B. McDaniel (Eds.), Liberating life: Contemporary approaches to ecological theology. Maryknoll, New York: Orbis Books.

Boff, L. (2012). The contribution of Christianity to sustainability. In R. Clugston and S. Holt (Eds.), Exploring synergies between faith values and Education for Sustainable Development. Retrieved from http://www.earthcharter.org

Browning, G. (2012). Planet earth: Christian values and principles for sustainability. In R. Clugston and S. Holt (Eds.), Exploring synergies between faith values and Education for Sustainable Development. Retrieved from http://www.earthcharter.org

Ezeh, M. N. E. (2012). Poverty and environmental decline: Advocacy of ethical strategy of respect for creation for a sustainable community. African Journal of Arts and Cultural Studies, 5(2), 17-22. 
Grandberg, M. (1991). Covenant and creation. In C. Birch, W. Eakin, and J. B. McDaniel (Eds.), Liberating life: Contemporary approaches to ecological theology. Maryknoll, New York: Orbis Books.

Haught, J. F. (1995). Science and religion: From conflict to conversation. New York: Paulist Press.

John Paul II. (1981). Laborem Exercens (On human work). In J. Gremillion (Ed.), The Gospel of peace and justice: Catholic social teaching since Pope John. Maryknoll, New York: Orbis Books.

John Paul II. (1989). Centesimus Annus (Hundredth year). Kenya: Pauline Publications.

John Paul II. (1990). Christians and ecological crisis: World Day of Peace message. Dublin: Irish Commission for Justice and Peace.

John XXIII. (1961). Mater et Magister (On social progress). In J. Gremillion (Ed.), The Gospel of peace and justice: Catholic social teaching since Pope John. Maryknoll, New York: Orbis Books.

John XXIII. (1963). Pacem in Terris (Peace on Earth). In J. Gremillion (Ed.), The Gospel of peace and justice: Catholic social teaching since Pope John. Maryknoll, New York: Orbis Books.

Leo XIII. (1891). Rerum Novarum (On the condition of workers). Kenya: Paulines Publication.

Mansour, M. (2012). Orthodox Christianity and Education for Sustainable Development (ESD). In R. Clugston and S. Holt (Eds.), Exploring synergies between faith values and Education for Sustainable Development. Retrieved from http://www.earthcharter.org

McDonagh, S. (1994). Passion for the Earth: The Christian vocation to promote justice, peace and integrity of creation. London: Geoffry Champman.

Millennium Development Goals (MDGs). (2000). Retrieved from http://www.un.org/millennium/summit.htm

Pius XI. (1931). Quadragesimo Anno (In the 40th year). London: Catholic Truth Society.

Stoutzenberger, J. (2012). Science and faith: A new introduction. New York: Paulist Press.

UNESCO (United Nations Educational, Scientific, and Cultural Organization). (2002). UNESCO and sustainable development. Retrieved from http://www.unesco.org/education/desd

Vatican II. (1965). Gaudium et Spes (On the church in the modern world). In J. Gremillion (Ed.), The Gospel of peace and justice: Catholic social teaching since Pope John. Maryknoll, New York: Orbis Books. 